Correspondence Ronald S. Oremland roremlan@usgs.gov

\section{Alkalilimnicola ehrlichii sp. nov., a novel, arsenite- oxidizing haloalkaliphilic gammaproteobacterium capable of chemoautotrophic or heterotrophic growth with nitrate or oxygen as the electron acceptor}

\author{
Shelley E. Hoeft, ${ }^{1}$ Jodi Switzer Blum, ${ }^{1}$ John F. Stolz, ${ }^{2}$ F. Robert Tabita, ${ }^{3}$ \\ Brian Witte, ${ }^{3}$ Gary M. King, ${ }^{4}$ Joanne M. Santini ${ }^{5}$ and Ronald S. Oremland ${ }^{1}$ \\ ${ }^{1}$ US Geological Survey, 345 Middlefield Road, MS 480, Menlo Park, CA 94025, USA \\ ${ }^{2}$ Department of Biological Sciences, Duquesne University, Pittsburgh, PA 15282, USA \\ ${ }^{3}$ Department of Microbiology, The Ohio State University, Columbus, OH 43210, USA \\ ${ }^{4}$ Darling Marine Center, University of Maine, Walpole, ME 04573, USA \\ ${ }^{5}$ Department of Biology, UCL, London WC1E 6BT, UK
}

\begin{abstract}
A facultative chemoautotrophic bacterium, strain $\mathrm{MLHE}-1^{\top}$, was isolated from Mono Lake, an alkaline hypersaline soda lake in California, USA. Cells of strain MLHE-1 ${ }^{\top}$ were Gram-negative, short motile rods that grew with inorganic electron donors (arsenite, hydrogen, sulfide or thiosulfate) coupled with the reduction of nitrate to nitrite. No aerobic growth was attained with arsenite or sulfide, but hydrogen sustained both aerobic and anaerobic growth. No growth occurred when nitrite or nitrous oxide was substituted for nitrate. Heterotrophic growth was observed under aerobic and anaerobic (nitrate) conditions. Cells of strain MLHE-1 ${ }^{\top}$ could oxidize but not grow on $\mathrm{CO}$, while $\mathrm{CH}_{4}$ neither supported growth nor was it oxidized. When grown chemoautotrophically, strain $\mathrm{MLHE}-1^{\top}$ assimilated inorganic carbon via the Calvin-Benson-Bassham reductive pentose phosphate pathway, with the activity of ribulose 1,5-bisphosphate carboxylase (RuBisCO) functioning optimally at $0.1 \mathrm{M} \mathrm{NaCl}$ and at $\mathrm{pH}$ 7.3. Strain $\mathrm{MLHE}-1^{\top}$ grew over broad ranges of $\mathrm{pH}$ (7.3-10.0; optimum, 9.3), salinity (15-190 $\mathrm{g} \mathrm{I}^{-1}$; optimum $30 \mathrm{~g} \mathrm{I}^{-1}$ ) and temperature $\left(13-40^{\circ} \mathrm{C}\right.$; optimum, $30^{\circ} \mathrm{C}$ ). Phylogenetic analysis of $16 \mathrm{~S}$ rRNA gene sequences placed strain MLHE-1 ${ }^{\top}$ in the class Gammaproteobacteria (family Ectothiorhodospiraceae) and most closely related to Alkalispirillum mobile (98.5\%) and Alkalilimnicola halodurans (98.6\%), although none of these three haloalkaliphilic micro-organisms were capable of photoautotrophic growth and only strain MLHE- $1^{\top}$ was able to oxidize As(III). On the basis of physiological characteristics and DNA-DNA hybridization data, it is suggested that strain $\mathrm{MLHE}-1^{\top}$ represents a novel species within the genus Alkalilimnicola for which the name Alkalilimnicola ehrlichii is proposed. The type strain is MLHE-1 ${ }^{\top}$ $\left(=\mathrm{DSM} 17681^{\top}=\right.$ ATCC BAA $\left.-1101^{\top}\right)$. Aspects of the annotated full genome of Alkalilimnicola ehrlichii are discussed in the light of its physiology.
\end{abstract}

\section{INTRODUCTION}

Arsenic is a toxic metal(loid) of environmental concern. Despite its toxicity, certain microbes have evolved that can utilize arsenic for energy generation. Arsenic generally occurs in aquatic environments as either arsenate $\left[\mathrm{HAsO}_{4}^{2-}\right.$ or $\mathrm{As}(\mathrm{V})]$ or arsenite $\left[\mathrm{H}_{2} \mathrm{AsO}_{3}^{-}\right.$or $\left.\mathrm{As}(\mathrm{III})\right]$, the latter oxyanion being more toxic than the former. The first As(III)-oxidizing micro-organism was isolated by Green (1918) and since then several prokaryotes with this aerobic

Abbreviations: AODC, acridine orange direct counts; PHB, polyhydroxybutyrate; RuBisCo, ribulose 1,5-bisphosphate carboxylase.

Further details of the methods used for PCR amplification and gene fragment analysis, graphs showing the growth of strain MLHE-1 ${ }^{\top}$ under varying temperature, salinity and $\mathrm{pH}$ conditions, an additional phylogenetic tree, a plot showing RuBisCO activity in cell extracts of MLHE-1 ${ }^{\top}$ and tables detailing lithotrophic growth of the novel strain on a variety of inorganic electron donors and on a diversity of organic and one-carbon electron donors are available as supplementary material in IJSEM Online. 
metabolic capability have been described. Phylogenetically diverse, they include members of the Alphaproteobacteria and the Betaproteobacteria (Oremland \& Stolz, 2003). As(III) oxidation has been noted in both heterotrophic and chemoautotrophic bacteria that have been isolated from a number of As-rich environments including cattle-dipping fluids, soils, sewage, mine drainage and hot springs (Ehrlich, 2002; Santini et al., 2000; Salmassi et al., 2002; Stolz et al., 2006).

Thermus aquaticus and Thermus thermophilus were found to rapidly oxidize $\mathrm{As}(\mathrm{III})$ to $\mathrm{As}(\mathrm{V})$, but were unable to grow with As(III) as the sole energy source (Gihring et al., 2001). Similarly, Hydrogenophaga sp. strain NT-14 oxidized As(III) but, although it did not grow as a chemoautotroph, it nonetheless gained a small amount of energy from the reaction (vanden Hoven \& Santini, 2004). Strain NT-26, a member of the Rhizobium clade of the Alphaproteobacteria, grew either as a chemoautotroph by oxidizing As(III) or as a heterotroph (Santini et al., 2000). The arsenite oxidases of these aerobic bacteria constitute a separate group within the broad family of molybdenum-containing enzymes and are composed of two heterologous subunits: the larger $(\sim 88 \mathrm{kDa}) \quad$ Mo-containing reactive centre protein and the smaller protein $(\sim 14 \mathrm{kDa})$ that contains a high potential Rieske functional group (Silver \& Phung, 2005). In heterotrophic As(III) oxidizers, the enzyme is designated Aox, while in autotrophic As(III) oxidizers, it is designated Aro. Nonetheless, the Aro/Aox enzymes for both chemoautotrophs and heterotrophs that oxidize As(III) are, with some variations in amino acid sequences and in the multiplicity of their corresponding large and small subcomponents, essentially of the same genre (vanden Hoven \& Santini, 2004; Santini \& vanden Hoven, 2004).

In contrast to the above examples of aerobic As(III) oxidation, little is known about anaerobic arsenite oxidation. We first observed this phenomenon in experiments with nitrate- or nitrite-amended anoxic bottom waters of Mono Lake, California, USA (Hoeft et al., 2002). An anaerobic, arsenite-oxidizing bacterium, strain MLHE- $1^{\mathrm{T}}$, was isolated from the waters of this alkaline $(\mathrm{pH} 9.8)$, saline (salinity $\sim 90 \mathrm{~g} \mathrm{l}^{-1}$ ) soda lake (Oremland et al., 2002). Nitrate-linked As(III) oxidation has also been reported in As-contaminated freshwater lakes (Senn \& Hemond, 2002), in lab-incubated aquifer materials (S. Reyes, personal communication) and possibly in Bangladesh subsurface sediments where injection of nitrate into groundwater resulted in the immobilization of arsenic, presumably as As(V) adsorbed onto iron(III) oxides (Harvey et al., 2002). Hence, microbial nitrate-linked As(III) is likely to be more widespread in nature than would be suggested by its occurrence in the extreme environment of Mono Lake. Indeed, Rhine et al. (2006) recently reported the isolation of two novel strains of As(III)-denitrifying chemoautotrophs from As-contaminated soils. The strains, DAO-10 and DAO-1, were aligned on the basis of their $16 \mathrm{~S}$ rRNA gene sequences within the classes Alphaproteobacteria and Betaproteobacteria, respectively.
Here we report the further characterization of strain MLHE$1^{\mathrm{T}}$ which grows under anaerobic conditions using $\mathrm{As}(\mathrm{III})$ as the electron donor, nitrate as the electron acceptor and $\mathrm{CO}_{2}$ (as bicarbonate) as the carbon source. Strain MLHE- $1^{\mathrm{T}}$ is proposed as a non-photosynthetic, novel species of the genus Ectothiorhodospira of the class Gammaproteobacteria.

\section{METHODS}

Culture conditions and strain characterization. Strain MLHE$1^{\mathrm{T}}$ was isolated from Mono Lake water and maintained in an anaerobic liquid basal salts medium as described previously (Oremland et al., 2002) with $10 \mathrm{mM} \mathrm{As(III)} \mathrm{as} \mathrm{the} \mathrm{electron} \mathrm{donor} \mathrm{and} 10 \mathrm{mM}$ nitrate as the electron acceptor. Cells were also grown under heterotrophic conditions with $10 \mathrm{mM}$ acetate as the electron donor and either oxygen (air head space) or $10 \mathrm{mM}$ nitrate as the electron acceptor. Solid media were prepared by mixing $4 \%(\mathrm{w} / \mathrm{v})$ agar and double strength of the above basal salts media at $55-60{ }^{\circ} \mathrm{C}$. Single colonies on solid media were grown aerobically with acetate as the electron donor. The standard growth conditions for the characterization of strain MLHE- $1^{\mathrm{T}}$ were $28^{\circ} \mathrm{C}$, pH 9.8 and $6 \% \mathrm{NaCl}$. Further experimental details on the ability of this organism to grow over wide ranges of $\mathrm{pH}$, salinity and temperature, as well as its substrate affinities are presented as supplementary material in IJSEM Online.

Electron microscopy. For transmission electron microscopy, cells of $\mathrm{MLHE}-1^{\mathrm{T}}$ were grown either heterotrophically on plates or chemoautotrophically in liquid medium. Cells were fixed with $2.5 \%$ glutaraldehyde in phosphate-buffered saline (plates) or by the addition of glutaraldehyde directly to the medium (liquid cultures) at a final concentration of $2.5 \%$. Negative staining of whole cells was performed with $1 \%$ uranyl acetate on Formvar-coated grids. Thin sections of Spurr's embedded samples were prepared following the procedure described by Switzer Blum et al. (1998). Samples were observed with a transmission electron microscope (100CX; JEOL) at $60 \mathrm{kV}$.

Arsenic metabolism and amplification of aroA. All of the known aroA gene sequences were aligned using CLUSTAL_X and conserved regions were identified. Primers were designed that would amplify a region of $\sim 530 \mathrm{bp}$. These primers contained the Pst I recognition sequence (underlined) and were: AroAdegF, 5'-GCCTGCAGGTCGGYTGYGGMTAYCAYGYYTA-3' (binds at nucleotide position 85-108; numbering according to the aroA gene sequence of strain NT-26) and AroAdeg2R, 5'-GCCTGCAGYTCDGARTTGTAGGCYGGBCG-3' (binds at nucleotide position 622-599 on the aro $A$ gene sequence of NT-26). PCR conditions involved incubation at $90{ }^{\circ} \mathrm{C}, 3 \mathrm{~min}$ (1st cycle only); $92^{\circ} \mathrm{C}, 1 \mathrm{~min} ; 45-50{ }^{\circ} \mathrm{C}, 1.5 \mathrm{~min}$; $72^{\circ} \mathrm{C}, 1 \mathrm{~min} ; 72^{\circ} \mathrm{C}, 5 \mathrm{~min}$ (final cycle only) for 40 cycles. PCRs contained $100 \mathrm{ng}$ DNA, $100 \mathrm{ng}$ each primer, $10 \%(\mathrm{v} / \mathrm{v})$ DMSO and GoTaq Green Master Mix (Promega). Chromosomal DNA of strain MLHE- $1^{\mathrm{T}}$ was isolated using the Wizard Genomic DNA Purification Kit (Promega) and the method described by Humphreys et al. (1975) was used to detect the presence of a plasmid. No plasmid was detected.

Phylogenetic analysis. Sequences of the 16S rRNA genes of the closest relatives of strain MLHE- $1^{\mathrm{T}}$ based on a BLAST search were obtained from GenBank. Sequence alignments were performed using CLUSTAL_X and a phylogenetic tree was constructed with maximumparsimony using PAUP* 4.0b (Swofford, 2002).

The $\mathrm{G}+\mathrm{C}$ content of the DNA (mol\%) was determined by total genome analysis courtesy of the DOE Joint Genome Institute (http:// genome.jgi-psf.org/draft_microbes/alkeh/alkeh.home.html). 
Optical DNA-DNA hybridization assays of strain MLHE- $1^{\mathrm{T}}$ against Alkalilimnicola halodurans DSM $13718^{\mathrm{T}}$ and Alkalispirillum mobile DSM $12769^{\mathrm{T}}$ were conducted in duplicate at the Deutsche Sammlung von Mikroorganismen und Zellkulturen (DSMZ) using $10 \%$ formamide in SSC buffer at $69^{\circ} \mathrm{C}$ (Huß et al., 1983).

Metabolism of $\mathbf{C H}_{\mathbf{4}}$. A $1 \mathrm{ml}$ sample of cells of strain MLHE- $1^{\mathrm{T}}$ was inoculated into $25 \mathrm{ml}$ 'Balch'-type culture tubes containing $10 \mathrm{ml}$ basal salts medium sealed under a gas phase of $5 \% \mathrm{CH}_{4}$ in air. Tubes were incubated at $28^{\circ} \mathrm{C}$ with constant reciprocal shaking (150 r.p.m.). Growth was also attempted using $250 \mathrm{ml}$ conical flasks containing $75 \mathrm{ml}$ basal salts medium inoculated with $10 \mathrm{ml}$ live cell suspensions sealed under a head space of $50 \% \mathrm{CH}_{4}$ and $50 \%$ air. Flasks were incubated at $30^{\circ} \mathrm{C}$ with rotary shaking ( $\sim 150$ r.p.m.). After 3 weeks of incubation, the head space was aseptically changed to 1000 p.p.m. $\mathrm{CH}_{4}$ in air and further monitored for $\mathrm{CH}_{4}$ consumption. Growth in both experiments was measured by acridine orange direct counts (AODC; Hobbie et al., 1977). A final washed cell suspension experiment was conducted using cells grown with acetate under air. Cells were centrifuged and washed three times with basal salts medium and then resuspended to a final cell density of

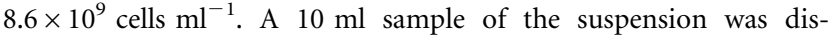
pensed into $37 \mathrm{ml}$ serum bottles and sealed under an air atmosphere with 1000 or 100 p.p.m. $\mathrm{CH}_{4}$. The suspensions were incubated at $30{ }^{\circ} \mathrm{C}$ with rotary shaking ( 150 r.p.m.). $\mathrm{CH}_{4}$ consumption in the above experiments was tracked by flame ionization gas chromatography (Oremland et al., 2005).

Metabolism of co. Alkalilimnicola halodurans, Alkalispirillum mobile and strain MLHE- $1^{\mathrm{T}}$ were grown under an air head space to stationary phase at $30{ }^{\circ} \mathrm{C}$ in stoppered $160 \mathrm{ml}$ serum bottles containing $10 \mathrm{ml}$ basal salts medium with $0.05 \%$ yeast extract and $25 \mathrm{mM}$ pyruvate in an artificial Mono Lake medium (King, 2003a). CO was added to the bottle head spaces (air, $1.3 \% \mathrm{O}_{2}$ in $\mathrm{N}_{2}$ or $100 \% \mathrm{~N}_{2}$ ) at starting concentrations ranging from 5 p.p.m. to $30 \% \mathrm{v} / \mathrm{v}$. Nitrate $(10 \mathrm{mM})$ was included as the electron acceptor for cells incubated under $\mathrm{N}_{2}$ and a nitrate-free condition served as a live control. Head space subsamples were obtained at intervals using a needle and syringe; $\mathrm{CO}$ concentrations were determined by $\mathrm{GC}$ as previously described (King, 2003b). Details of the PCR amplification and analysis of coxL gene fragments are given in the supplementary material available in IJSEM Online.

Determination of RuBisCo activity. Details of the methods used for determination of RuBisCO activity in cell extracts are given in the supplementary material available in IJSEM Online.

\section{RESULTS AND DISCUSSION}

\section{Cell morphology and ultrastructure}

Strain MLHE- $1^{\mathrm{T}}$ was isolated in a defined basal salts medium from Mono Lake anoxic bottom water (Oremland et al., 2002). Strain MLHE- $1^{\mathrm{T}}$ is a rod-shaped bacterium with a length of approximately $1.5-2.5 \mu \mathrm{m}$ and a diameter of $0.3-0.5 \mu \mathrm{m}$ and has a negative reaction to Gram staining. Cells from liquid culture exhibit active motility when viewed by phase-contrast microscopy. TEM observations of negatively stained cells revealed a single polar flagellum along with several pili (Fig. 1a). Thin sections of cells grown on acetate revealed the presence of polyhydroxybutyrate (PHB) storage granules in the cytoplasm (Fig. 1b), while cells grown autotrophically (arsenite) lacked PHB granules, but instead contained intracellular inclusions (Fig. 1c).

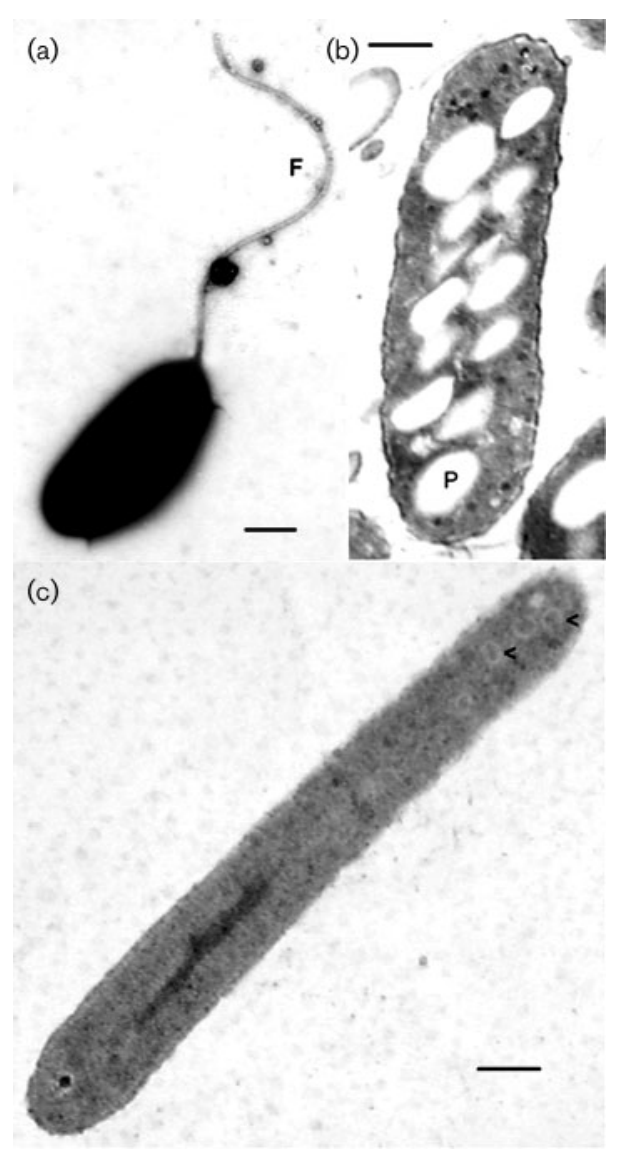

Fig. 1. Electron micrographs of cells of strain $\mathrm{MLHE}-1^{\top}$. (a) Negatively stained cell grown heterotrophically on plates. F, flagellum. (b) Thin section of a cell grown heterotrophically on plates showing PHA globules (P). (c) Thin section of a cell grown autotrophically. Arrows point to intracellular inclusions. Bars, $0.25 \mu \mathrm{m}$.

\section{Growth and physiological characterization}

Colonies on aerobic agar plates with acetate as the electron donor appeared after 14 days of incubation at $28{ }^{\circ} \mathrm{C}$ and were circular, convex, smooth and approximately $1 \mathrm{~mm}$ in diameter. Cells did not show any pigmentation when grown either on plates or in liquid culture and either in the dark or exposed to light. Growth occurred over a salinity range of $15-190 \mathrm{~g} \mathrm{l}^{-1}\left(0-175 \mathrm{~g} \mathrm{l}^{-1}\right.$ of added $\left.\mathrm{NaCl}\right)$, with an optimum at $30 \mathrm{~g} \mathrm{l}^{-1}\left(15 \mathrm{~g} \mathrm{l}^{-1}\right.$ added $\left.\mathrm{NaCl}\right)$. Strain MLHE$1^{\mathrm{T}}$ is alkaliphilic and exhibited an optimum growth rate at $\mathrm{pH}$ 9.3, but was unable to grow above $\mathrm{pH}$ 10.4. Optimum growth occurred at $30^{\circ} \mathrm{C}$ (see Supplementary Fig. $\mathrm{S} 1$ in IJSEM Online).

\section{Electron donors and acceptors}

Strain MLHE- $1^{\mathrm{T}}$ has been previously shown to be capable of anaerobic, chemoautotrophic growth with either $\mathrm{As}(\mathrm{III}), \mathrm{H}_{2}$ or sulfide serving as the electron donor and with $\mathrm{NO}_{3}^{-}$as the electron acceptor (Oremland et al., 2002). Strain MLHE- ${ }^{\mathrm{T}}$ 
also grew autotrophically on thiosulfate with nitrate as the electron acceptor (see Supplementary Table S1 in IJSEM Online). Under experimental conditions, strain MLHE- $1^{\mathrm{T}}$ did not grow with oxygen as the electron acceptor with either As(III), sulfide or thiosulfate serving as electron donors, but enhanced aerobic growth on hydrogen was noted. Anaerobic growth was also noted on the As(III)containing minerals orpiment and realgar, which were soluble in the alkaline basal salts medium, but no growth was noted with insoluble arsenopyrite. No growth was noted on a number of other potential inorganic electron donors, including $\mathrm{Fe}(\mathrm{II}), \mathrm{NO}_{2}^{-}, \mathrm{Mn}(\mathrm{II})$ and $\mathrm{Sb}(\mathrm{III})$.

Heterotrophic growth occurred on several organic acids, but not on any of the sugars or amino acids tested (see Supplementary Table S2 in IJSEM Online). Aerobic growth was observed on the following complex substrates: yeast extract, Casamino acids and casitone, but when nitrate served as the electron acceptor, growth occurred only on yeast extract. Growth did not occur with the following electron donors when $\mathrm{As}(\mathrm{V})(10 \mathrm{mM})$ was provided as the electron acceptor: lactate $(10 \mathrm{mM})$, pyruvate $(10 \mathrm{mM})$, succinate $(10 \mathrm{mM})$, acetate $(10 \mathrm{mM})$, glucose $(10 \mathrm{mM})$, hydrogen $(100 \%$ in head space), sulfide $(4 \mathrm{mM})$, yeast extract $(0.5 \%)$, Casamino acids $(0.3 \%)$ or casitone $(0.3 \%)$ (not shown). Finally, growth was not observed when $\mathrm{N}_{2} \mathrm{O}$ replaced nitrate and with acetate, As(III) or sulfide serving as the electron donors (not shown).

\section{Amplification of aroA}

Attempts to amplify a portion of the aroA gene of strain MLHE- $1^{\mathrm{T}}$ were unsuccessful and no amplicons were obtained. Indeed, a BLAST search of the genome for homologues of the aro $A$ gene did not turn up any positive responses, despite the confirmed ability of this organism to grow as a lithoautotroph using As(III) with nitrate (but not oxygen) as its electron acceptor (Supplementary Table S1; Oremland et al., 2004). Interestingly, two homologues of dissimilatory arsenate reductase $(\operatorname{arr} A)$ were identified as well as genes for arsenic resistance $(\operatorname{ars} C)$. Nevertheless, strain MLHE- $1^{\mathrm{T}}$ was not able to grow using $\mathrm{As}(\mathrm{V})$ as an electron acceptor (Supplementary Table S1), nor did it produce As(III) when grown aerobically as a heterotroph in the presence of $5 \mathrm{mM} \mathrm{As}(\mathrm{V})$.

\section{Phylogenetic analysis}

The 16S rRNA gene sequence for strain MLHE- $1^{\mathrm{T}}$ has been published previously (Oremland et al., 2002). However, four novel strains belonging to the genus have been isolated and characterized recently (Sorokin et al., 2006). These novel strains, Alkalilimnicola sp. AHN1, Alkalilimnicola sp. Z7008, Alkalilimnicola sp. AGDZ and Alkalilimnicola sp. ALPS2, share $98.8,98.3,98.2$ and $97.3 \%$ gene sequence similarity with strain MLHE- $1^{\mathrm{T}}$ and, along with Alkalilimnicola halodurans (98.6\% gene sequence similarity) and Alkalispirillum mobile (98.5\% similarity), form a tight clade (Fig. 2).

The DNA G + C content of strain MLHE- $1^{\mathrm{T}}$ is $67.5 \mathrm{~mol} \%$ and is similar to that of Alkalispirillum mobile (66.2 mol\%) and Alkalilimnicola halodurans (65.6 mol\%) (Table 1). Since the $\mathrm{G}+\mathrm{C}$ contents of DNA from these strains were so similar, hybridizations of DNA from strain MLHE- ${ }^{\mathrm{T}}$ to DNA from Alkalispirillum mobile and Alkalilimnicola halodurans were performed. The DNA-DNA relatedness values (duplicates) of strain MLHE- $1^{\mathrm{T}}$ with Alkalilimnicola

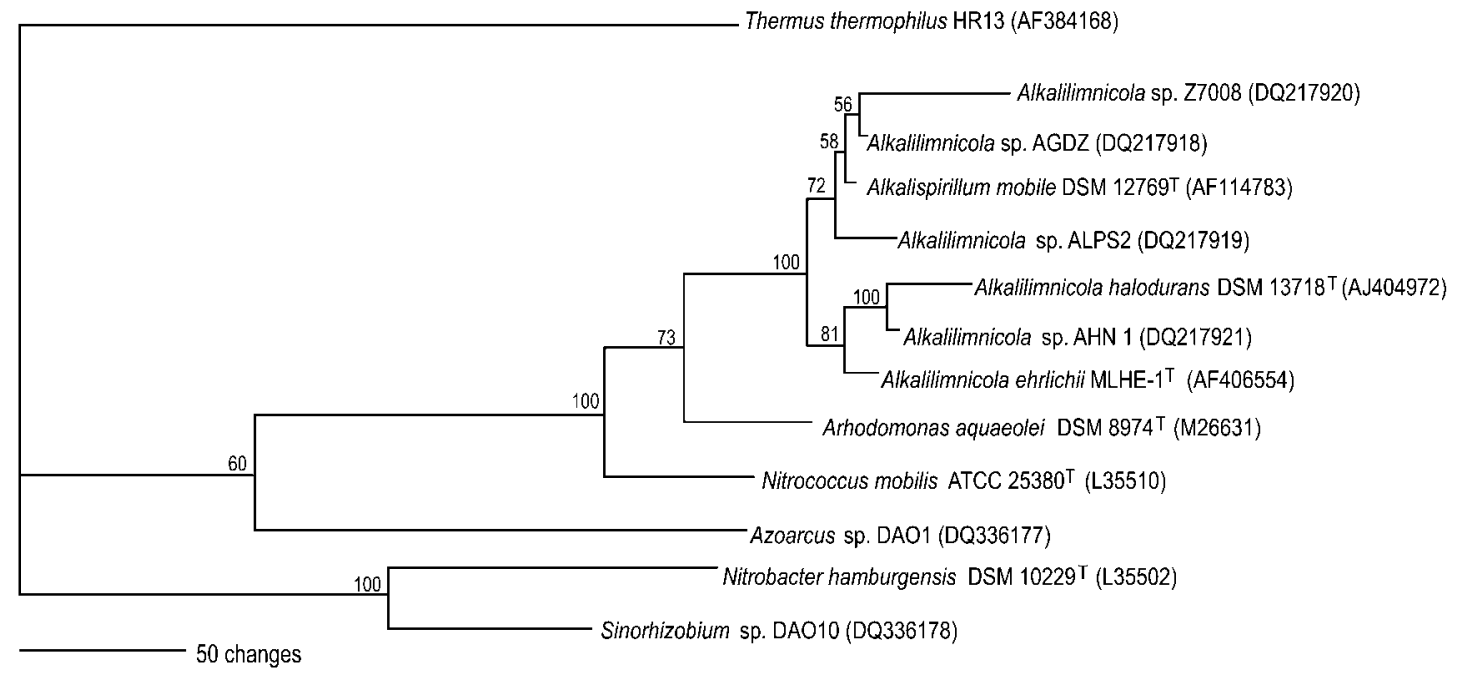

Fig. 2. Phylogenetic tree (maximum-parsimony) showing the relatedness of strain $M L H E-1^{\top}$ to known arsenite-oxidizing prokaryotes including the two arsenite-oxidizing denitrifiers Azoarcus sp. DAO1 and Sinorhizobium sp. DAO10 (Rhine et al., 2006) and the recently described Alkalilimnicola species (Sorokin et al., 2006). Accession numbers for strains are given in parentheses. Bar, 50 changes. 
Table 1. Comparison of characteristics of strain $\mathrm{MLHE}-1^{\top}$ and those of its two closest taxonomic relatives

Taxa; 1, strain MLHE-1 ${ }^{\mathrm{T}}$; 2, Alkalilimnicola halodurans; 3, Alkalispirillum mobile. +, Positive growth; - , no growth.

\begin{tabular}{|lccc|}
\hline Characteristic & $\mathbf{1}$ & $\mathbf{2}$ & $\mathbf{3}$ \\
\hline Morphology & Rods & Oval rods & Vibrio \\
Salinity range $\left(\mathrm{NaCl} \mathrm{g} \mathrm{l}^{-1}\right)$ & $0-175$ & $0-280$ & $0-250$ \\
Salinity optimum $\left(\mathrm{NaCl} \mathrm{g} \mathrm{l}^{-1}\right)$ & 15 & $30-80$ & 20 \\
$\mathrm{pH}$ optimum & 9.3 & 9.5 & $9-10$ \\
Temperature optimum $\left({ }^{\circ} \mathrm{C}\right)$ & 30 & $20-50$ & $35-38$ \\
DNA G+C content $(\mathrm{mol} \%)$ & 67.5 & 65.6 & 66.2 \\
Mobility & Single, polar flagellum & Subpolar flagella & Single, polar flagellum \\
Substrates for growth & & & - \\
$($ electron acceptor $10 \mathrm{mM} \mathrm{nitrate)}$ & & - & - \\
$10 \mathrm{mM}$ As(III) & + & - & + \\
$100 \%$ H & + & + & \\
$4 \mathrm{mM}$ sulfide & + & & \\
\hline
\end{tabular}

halodurans (45.7\%; 42.6\%) and Alkalispirillum mobile $(14.7 \% ; 28.8 \%)$ were lower than the recommended value of $70 \%$ DNA-DNA similarity for strains belonging to the same species (Wayne et al., 1987). Because of the much closer similarity of strain MLHE- $1^{\mathrm{T}}$ to members of the genus Alkalilimnicola, it is proposed that strain MLHE- $^{\mathrm{T}}$ represents a novel species in this genus.

\section{Arsenite oxidation in closely related species}

Two species closely related to strain MLHE- $1^{\mathrm{T}}$ were tested for their ability to grow by oxidizing As(III), hydrogen and sulfide with nitrate as the electron acceptor (Table 1). Neither Alkalispirillum mobile nor Alkalilimnicola halodurans were capable of oxidizing As(III) or hydrogen with nitrate; however, both strains were able to oxidize sulfide with nitrate and growth was confirmed for both by AODC. Growth did not occur with arsenite when oxygen was provided as the electron acceptor (data not shown). Alkalispirillum mobile was isolated from cultures of an anoxygenic phototroph (Halorhodospira halophila SL-1) which originated from Summer Lake, Oregon, USA, and is a moderately halophilic and alkaliphilic bacterium originally described as being obligately aerobic (Rijkenberg et al., 2001). Alkalilimnicola halodurans was isolated from phototrophic enrichments from Lake Natron sediments and is an alkaliphilic and halotolerant bacterium. Originally described as having the ability to grow anaerobically with nitrate, the denitrifying ability of the strain was not studied in detail and neither was its capability for lithoautotrophy (Yakimov et al., 2001). Sorokin et al. (2006) recently reported that Alkalispirillum mobile and Alkalilimnicola halodurans are capable of full denitrification (reduction of nitrate to $\mathrm{N}_{2}$ ) with acetate as the electron donor. They also report on the identification of four new isolates from the Alkalispirillum-Alkalilimnicola group capable of anaerobic growth with acetate using either nitrate or $\mathrm{N}_{2} \mathrm{O}$ as the electron acceptor, which would indicate that they also have lesion(s) at the level of nitrite reductase. It is quite possible that certain key genetic elements of enzyme complexes, such as those involved in denitrification, have been deleted with time due to genome turnover arising from either acquisition of new DNA or egress of key DNA sequences. In so doing, altered gene sequences (pseudogenes) can become nonfunctional, but may still retain sufficient similarity to functional genes as to suggest that they are operational (Ochman \& Davalos, 2006). Such a mechanism would explain the occurrence of annotated gene homologues for full denitrification in strain MLHE- $1^{\mathrm{T}}$ which is at odds with some of our physiological tests (for example, growth with $\mathrm{N}_{2} \mathrm{O}$ as an electron acceptor). Indeed, this explanation can also be offered for the absence of methane metabolism in strain MLHE- ${ }^{\mathrm{T}}$ (see below).

\section{Metabolism of $\mathbf{C H}_{4}$}

No growth or consumption of the $1 \% \mathrm{CH}_{4}$ head space was observed during incubation of shaken culture tubes (data not shown) or of the conical flasks $\left(50 \% \mathrm{CH}_{4}\right.$ in air) (see Supplementary Table S1). When the original flask head space was replaced with a $1 \% \mathrm{CH}_{4}$ in air mixture to allow monitoring of gas consumption, we did observe a nearcomplete loss of $\mathrm{CH}_{4}$ over an interval of about 3 weeks that continued upon the addition of more $\mathrm{CH}_{4}$ to the head space. Nonetheless, we were unable to attribute this observation to methane oxidation (as opposed to leakage) because incubated subaliquots of the aqueous phase neither consumed any added ${ }^{14} \mathrm{CH}_{4}$ nor produced ${ }^{14} \mathrm{CO}_{2}$ from this radiotracer (data not shown). When the flask experiment was repeated, no loss of head space $\mathrm{CH}_{4}$ was observed over prolonged incubation under identical conditions. In addition, no $\mathrm{CH}_{4}$ consumption was noted by washed cell suspensions. We conclude that strain $\mathrm{MLHE}-1^{\mathrm{T}}$ is not a 
methanotroph, nor does it have the ability to oxidize (but not grow on) $\mathrm{CH}_{4}$, as it apparently does for $\mathrm{CO}$ (see below).

Our tests for the presence of aerobic methanotrophy in strain MLHE- $1^{T}$ were prompted by the identification of a methane monooxygenase $\mathrm{C}$ homologue $(\mathrm{mmoC})$, formate dehydrogenase (e.g. $f d h A B C$ ) and a serine hydroxymethyltransferase $(g l y A)$ in the genome of the novel strain. The latter suggested the presence of at least a partial downstream mechanism for $\mathrm{C}_{1}$ oxidation and carbon fixation, with the former being confirmed by the ability of strain MLHE- $1^{\mathrm{T}}$ to grow on formate (see Supplementary Table S2 in IJSEM Online). However, the full complement of mmo genes is lacking from the genome of strain MLHE- $1^{\mathrm{T}}$ and no methanol dehydrogenase homologues were found. Type I methanotrophs of the genus Methylobacter dominate the methane-oxidizing flora of Mono Lake, but molecular signals ( $p m o A$ amplicons) were also found for Type II methanotrophs of the Methylocystis genus (Lin et al., 2005). It is conceivable that there may have been some conjugative transfer of DNA between Gammaproteobacteria of the Methylobacter type and those of the Ectothiorhodospira types such as strain MLHE- $1^{\mathrm{T}}$. However, Type I methanotrophs have the Calvin-Benson-Bassham pathway of $\mathrm{C}$ assimilation, while the genome of strain MLHE- $1^{\mathrm{T}}$ has annotation for the serine pathway, a feature of Type II methanotrophs of the Alphaproteobacteria (Anthony, 1982). The serine transhydroxymethyltransferase $(g l y A)$ may function in serine biosynthesis from glycine.

\section{Metabolism of CO}

Strain MLHE- ${ }^{\mathrm{T}}$ readily oxidized CO at a concentration range of between 100 and 1000 p.p.m. during stationary phase culture incubations (Fig. 3). When cultures were incubated with $30 \% \mathrm{CO}$ head space concentrations, uptake was initially negligible (7 days) and no growth was observed in the presence of this elevated level of CO. However, during extended incubations ( $>60$ days), strain MLHE- $1^{\mathrm{T}}$ reduced CO concentrations by about one-third to $20 \%$, but CO uptake was not coupled to an increase in cell density. Alkalispirillum mobile and Alkalilimnicola halodurans also oxidized $\mathrm{CO}$ at concentrations $<1000$ p.p.m., with activity by the former greater than the latter. In addition, Alkalispirillum mobile reduced $30 \%$ CO head space concentrations to values $<5 \%$ over a 60 day interval, but did not grow at the expense of $\mathrm{CO}$.

Cell suspensions of pyruvate-grown strain MLHE-1 ${ }^{\mathrm{T}}$ were able to consume trace concentrations of $\mathrm{CO}$ that mimicked ambient mixing levels of this gas in the lower troposphere. Cells oxidized the initially enclosed 5 p.p.m. CO and lowered the final head space concentrations to $<0.1$ p.p.m. ( $>99 \%$ oxidation) within a few days of incubation (data not shown). Activity was noted in cells incubated under air, under microaerophilic conditions $\left(1.3 \% \mathrm{O}_{2}\right)$ and under anaerobic conditions with nitrate as the electron acceptor. No significant CO oxidation by cells was noted under anaerobic conditions lacking nitrate. Anaerobic oxidation of

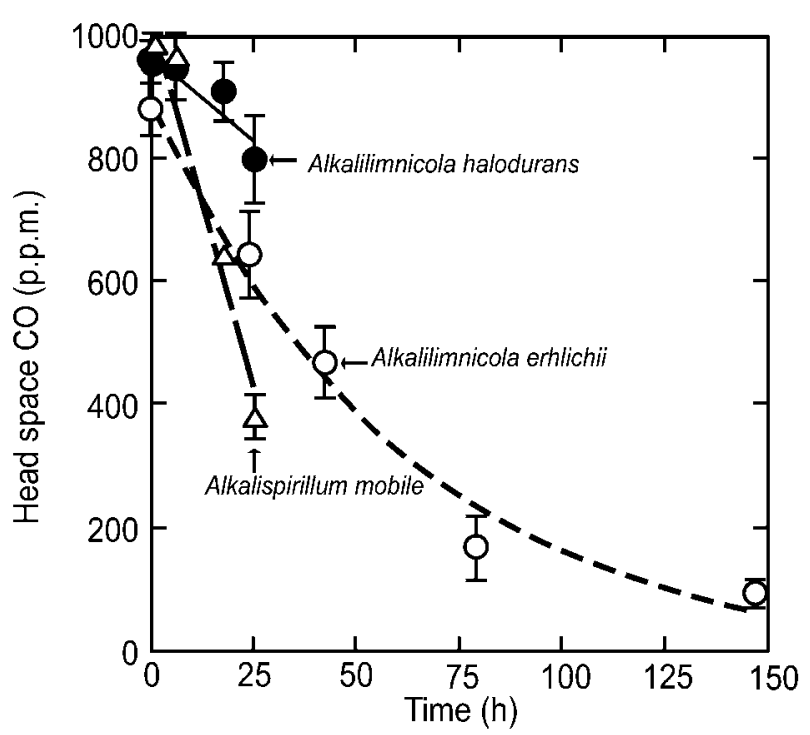

Fig. 3. Consumption of $\mathrm{CO}$ by cell suspensions of Alkalimnicola halodurans, strain MLHE-1 ${ }^{\top}$ and Alkalispirillum mobile. The values represent the mean of three cell suspensions and bars indicate $\pm 1 \mathrm{SD}$.

CO by several diverse nitrate-respiring bacteria has been recently reported (King, 2006).

PCR amplification of strain MLHE- $1^{\mathrm{T}}$ genomic DNA with primers specific for form I coxL resulted in a product, the sequence of which was identical to a sequence annotated as a putative large subunit $\mathrm{CO}$ dehydrogenase gene in the genome of strain MLHE- ${ }^{\mathrm{T}}$. This sequence clustered with other form I coxL partial gene sequences from members of the classes Betaproteobacteria and Gammaproteobacteria after a neighbour-joining phylogenetic analysis; bootstrap support was high $(82 \%$ for 1000 bootstrap replicates; see Supplementary Fig. S2 in IJSEM Online). As in the case of $\mathrm{CH}_{4}$ illustrated above, we were prompted to examine $\mathrm{CO}$ metabolism by strain MLHE- $1^{\mathrm{T}}$ as the genome annotation indicated the presence of a CO dehydrogenase operon that included all three structural genes (coxFEDLSM). In this instance, however, we not only found active uptake of $\mathrm{CO}$ in this species, as well as in two neighbouring species (Fig. 3), but we also successfully generated amplicons of coxL using established primer sets.

\section{RuBisCO activity}

Strain MLHE- $1^{\mathrm{T}}$ grows as a chemoautotroph as previously demonstrated by its ability to fix ${ }^{14} \mathrm{CO}_{2}$ (added as ${ }^{14} \mathrm{C}$ bicarbonate) into cell material and by successful amplification ( $\sim 800 \mathrm{bp}$ fragment) of the $c b b L$ gene of form 1 RuBisCO (Oremland et al., 2002). However, genome annotation indicates not only the presence of RuBisCO, with both large and small subunits (encoded by the $c b b L$ and $c b b S$ genes, respectively), but also the possible presence of components of a $\mathrm{C}_{4}$ or reverse TCA cycle (phosphoenolpyruvate carboxylase; $p p c$ ) and a serine pathway (see $\mathrm{CH}_{4}$ 
section above). Therefore, we conducted enzyme assays with cell extracts to test for the actual presence of RuBisCO activity. A lysate from cells of strain MLHE- $1^{\mathrm{T}}$ grown chemoautotrophically exhibited optimal RuBisCO activity at pH 7.7 and $140 \mathrm{mM}\left(8.2 \mathrm{~g} \mathrm{l}^{-1}\right) \mathrm{NaCl}$ (see Supplementary Fig. S3 in IJSEM Online). These results were consistent with previous studies of enzymes obtained from halo- and alkaliphilic bacteria (Tabita \& McFadden, 1976). At pH 8.5 $(140 \mathrm{mM} \mathrm{NaCl})$, lysates buffered with either Bicine- $\mathrm{NaOH}$ or CHES-NaOH showed nearly identical activities, indicating that CHES is an acceptable buffer at higher $\mathrm{pH}$ values. The lysate from strain MLHE- $1^{\mathrm{T}}$ strongly cross-reacted with antisera raised against the Synechococcus $6301 \mathrm{RuBisCO}$ and no cross-reactivity was observed using an antiserum that was raised against the Rhodospirillum rubrum form II enzyme (data not shown).

Maximal enzyme activities occurred at salinities and $\mathrm{pH}$ values that were considerably lower than those observed for optimal growth (see Supplementary Fig. S1). We attribute this result to the fact that the internal cytoplasmic $\mathrm{pH}$ and salinity of strain MLHE- ${ }^{\mathrm{T}}$ are circumneutral and of low salinity compared with that of its external milieu, a common attribute of extremophiles. In addition, the genome shows the presence of PEP carboxylase as an alternate means of $\mathrm{CO}_{2}$ fixation, however it is difficult to assess the presence of genes that encode the signature enzymes of the reductive TCA pathway in strain MLHE- $1^{\mathrm{T}}$ since these reversible catalysts (pyruvate-ferredoxin oxidoreductase and 2-oxoglutarate-ferredoxin oxidoreductase) may also function in purely heterotrophic metabolism. In no instance has a functional Calvin-Benson-Bassham pathway been shown to be used in concert with the reductive TCA pathway of $\mathrm{CO}_{2}$ assimilation, making it unlikely that the reductive TCA route is operational here.

\section{CONCLUSION}

Strain MLHE- $1^{\mathrm{T}}$ has a highly flexible metabolism, capable of growth either as a heterotroph or as a chemoautotroph, with the additional ability to use either nitrate or oxygen as electron acceptors. In Mono Lake, this would allow it to survive as a lithotroph by exploiting the chemical redox gradients occurring within oxic/anoxic boundaries (i.e. chemocline) imposed by either seasonal (monomixis) or prolonged (meromixis) water column stratification (Oremland et al., 2004). In such an environment, it could couple the oxidation of reduced constituents (arsenite, sulfide) diffusing upwards from the anoxic bottom water with downward diffusing oxidants (nitrate, oxygen) from the aerobic epilimnion or the suboxic portion of the chemocline. It could also sustain itself as a conventional heterotroph by feasting upon the sinking remains of decomposing phytoplankton and zooplankton blooms. However, its ecological significance and abundance within Mono Lake has yet to be determined, as a survey of microbial diversity in this system did not detect this strain (Humayoun et al., 2003).
Nonetheless, such a flexible metabolism has also been observed in other arsenite-oxidizing bacteria of terrestrial origin, be they aerobes like strain NT-26 (Santini et al., 2000) or denitrifiers like strains DAO1 and DAO10 (Rhine et al., 2006). Such metabolic flexibility would give such strains a competitive survival edge in aquifers, for example, where nitrate, organic electron donors and arsenic species may all be present but at variable concentrations in both time and space (Kent \& Fox, 2004). In the case of strains DAO1 and DAO10, they also exhibited similar autotrophic substrate affinities to strain MLHE- $1^{\mathrm{T}}$ in that they could only grow on $\mathrm{As}(\mathrm{III})$ with nitrate, but in the case of $\mathrm{H}_{2}$ were capable of aerobic or anaerobic growth (sulfide was not tested). These two strains conduct a full dissimilatory reduction of nitrate to $\mathrm{N}_{2}$ while MLHE- $1^{\mathrm{T}}$ will only reduce nitrate to nitrite and is incapable of $\mathrm{N}_{2} \mathrm{O}$ reduction. Preliminary analysis of the full genome of strain MLHE$1^{\mathrm{T}}$ indicates a functional operon for respiratory nitrate reductase (narLXK $\left.K_{2} G H J\right)$, as well as a nitric oxide reductase (norDQBC; Nor) and nitrous oxide reductase (nosLYDZR; Nos), but critically it lacks a respiratory nitrite reductase (nirK or nirS). Nevertheless, attempts to grow strain MLHE$1^{\mathrm{T}}$ on nitrous oxide were unsuccessful suggesting that Nor and Nos are inoperable (Zumft, 1997).

Finally, with regard to the oxidation of inorganic electron donors, the annotated genome of strain MLHE- $1^{\mathrm{T}}$ lists several hydrogenases ( $m b h L 3$, hupL; large and small subunits of 'nickel-iron hydrogenase'). A diversity of uptake hydrogenases could explain our observation of $\mathrm{H}_{2-}$ dependent growth under both aerobic and anaerobic conditions (see Supplementary Table S1). However, with regard to sulfide and arsenite oxidation, the genome data are ambiguous. No sox genes were detected, however, homologues of genes encoding a putative sulfide dehydrogenase and sulfite reductase (dsrABEFHCMKLJOP) have been identified. Nevertheless, determination of the enzyme(s) involved in these reactions awaits further biochemical analysis. Although we have clearly established that strain MLHE- $1^{\mathrm{T}}$ can oxidize arsenite, we have not, however, found evidence for homologues of arsenite oxidase, either the catalytic subunit (AroA) or the Rieske subunit (AroB), and our unsuccessful attempt to amplify an aroA-like sequence would tend to confirm its absence. The presence of two arrA homologues is also perplexing in that strain MLHE- $1^{\mathrm{T}}$ is unable to grow under anaerobic conditions by using $\mathrm{As}(\mathrm{V})$ as an electron acceptor. This suggests that either strain MLHE- $1^{\mathrm{T}}$ has a novel enzyme for oxidation of As(III) unrelated to Aro or that it employs one (or both) of its structurally similar Arr reductases (Silver \& Phung, 2005) to oxidize As(III) by running in the reverse direction.

\section{Description of Alkalilimnicola ehrlichii sp. nov.}

Alkalilimnicola ehrlichii (ehr.li' ch.ii. N.L. gen. n. ehrlichii of Ehrlich, named in honour of Professor Emeritus Henry Lutz Ehrlich for his broad scientific, teaching and leadership contributions to the field of geomicrobiology, with 
specific reference to his work on the bacterial oxidation of arsenite).

Cells are Gram-negative, motile rods (1.5-2.5 $\times$ $0.3-0.5 \mu \mathrm{m})$. Colonies on agar plates are circular, convex and smooth with a diameter of approximately $1 \mathrm{~mm}$ and are non-pigmented. The optimum $\mathrm{pH}$ and temperature are $\mathrm{pH} 9.3$ and $30^{\circ} \mathrm{C}$, respectively. Growth occurs over a salinity range of 15-190 $\mathrm{g} \mathrm{NaCl}^{-1}$, with an optimum of $30 \mathrm{~g} \mathrm{l}^{-1}$. Facultatively anaerobic and facultatively chemoautotrophic. Haloalkaliphilic. Non-phototrophic. Capable of growth with inorganic electron donors (arsenite, hydrogen, sulfide and thiosulfate) and nitrate as the electron acceptor. Heterotrophic growth is observed under both aerobic and anaerobic (nitrate) conditions on a variety of organic acids, but not on sugars (glucose, fructose or galactose) or alcohols (methanol, ethanol). Unable to grow aerobically with other inorganic electron donors, except with hydrogen. Autotrophic growth occurs via the Calvin-Benson-Bassham Cycle. The $\mathrm{G}+\mathrm{C}$ content of the DNA is $67.5 \mathrm{~mol} \%$.

The type strain, MLHE- $1^{\mathrm{T}}\left(=\right.$ DSM $17681^{\mathrm{T}}=$ ATCC BAA$\left.1101^{\mathrm{T}}\right)$, was isolated from Mono Lake, an alkaline hypersaline soda lake, in California, USA.

\section{ACKNOWLEDGEMENTS}

This work was supported in part by the US Geological Survey and a NASA Exobiology grant to R.S. O. and J.F.S. We are grateful to C. Spröer at DSM for the DNA-DNA relatedness analyses.

\section{REFERENCES}

Anthony, C. (1982). The Biochemistry of Methylotrophs. London: Academic Press.

Ehrlich, H. L. (2002). Bacterial oxidation of As(III) compounds. In Environmental Chemistry of Arsenic, pp. 313-328. Edited by W. T. Frankenberger, Jr. New York, USA: Marcel Dekker.

Gihring, T. M., Druschel, G. K., McCleskey, R. B., Hamers, R. J. \& Banfield, J. F. (2001). Rapid arsenite oxidation by Thermus aquaticus and Thermus thermophilus: field and laboratory investigations. Environ Sci Technol 35, 3857-3862.

Green, H. H. (1918). Description of a bacterium which oxidizes arsenite to arsenate, and one which reduces arsenate to arsenite, isolated from a cattle-dipping tank. S Afr J Sci 14, 465-467.

Harvey, C. F., Swartz, C. H., Badruzzaman, A. B., Keon-Blute, N., Yu, W., Ali, M. A., Jay, J., Beckie, R., Niedan, V. \& other authors (2002). Arsenic mobility and groundwater extraction in Bangladesh. Science 298, 1602-1606.

Hobbie, J. E., Daley, R. L. \& Jasper, S. (1977). Use of Nuclepore filters for counting bacteria for fluorescence microscopy. Appl Environ Microbiol 33, 1225-1228.

Hoeft, S. E., Lucas, F., Hollibaugh, J. T. \& Oremland, R. S. (2002). Characterization of microbial arsenate reduction in the anoxic bottom waters of Mono Lake, California. Geomicrobiol J 19, 23-40.

Humayoun, S. B., Bano, N. \& Hollibaugh, J. T. (2003). Depth distribution of microbial diversity in Mono Lake, a meromictic soda lake in California. Appl Environ Microbiol 69, 1030-1042.
Humphreys, G. O., Willshaw, G. A. \& Anderson, E. S. (1975). A simple method for the preparation of large quantities of pure plasmid DNA. Biochim Biophys Acta 383, 457-463.

Huß, V. A. R., Festl, H. \& Schleifer, K. H. (1983). Studies on the spectrophotometric determination of DNA hybridization from renaturation rates. Syst Appl Microbiol 4, 184-192.

Kent, D. B. \& Fox, P. M. (2004). The influence of groundwater chemistry on arsenic concentrations and speciation in a quartz sand and gravel aquifer. Geochem Trans 5, 1. doi: 10.1186/1467-4866-5-1

King, G. M. (2003a). Contributions of atmospheric CO and hydrogen uptake to microbial dynamics on recent Hawaiian volcanic deposits. Appl Environ Microbiol 69, 4067-4075.

King, G. M. (2003b). Molecular and culture-based analyses of aerobic carbon monoxide oxidizer diversity. Appl Environ Microbiol 69, 7257-7265.

King, G. M. (2006). Nitrate-dependent anaerobic carbon monoxide oxidation by aerobic CO-oxidizing bacteria. FEMS Microbiol Ecol 56, $1-7$.

Lin, J.-L., Joye, S. B., Scholten, J. C. M., Schäfer, H., McDonald, I. R. \& Murrell, J. C. (2005). Analysis of methane monooxygenase genes in Mono Lake suggests that increased methane oxidation activity may correlate with a change in methanotroph community structure. Appl Environ Microbiol 71, 6458-6462.

Ochman, H. \& Davalos, L. M. (2006). The nature and dynamics of bacterial genomes. Science 311, 1730-1733.

Oremland, R. S., \& Stolz, J. F. (2003). The ecology of arsenic. Science 300, 939-944.

Oremland, R. S., Hoeft, S. E., Santini, J. M., Bano, N., Hollibaugh, R. A. \& Hollibaugh, J. T. (2002). Anaerobic oxidation of arsenite in Mono Lake water and by a facultative, arsenite-oxidizing chemoautotroph, strain MLHE-1. Appl Environ Microbiol 68, 4795-4802.

Oremland, R. S., Stolz J. F. \& Hollibaugh, J. T. (2004). The microbial arsenic cycle in Mono Lake, California. FEMS Microbiol Ecol 48, $15-27$.

Oremland, R. S., Kulp, T. R., Switzer Blum, J., Hoeft, S. E., Baesman, S., Miller, L. G. \& Stolz, J. F. (2005). A microbial arsenic cycle in a salt-saturated, extreme environment. Science 308, 1305-1308.

Rhine, E. D., Phelps, C. D. \& Young, L. Y. (2006). Anaerobic arsenite oxidation by novel denitrifying isolates. Environ Microbiol 8, 899-908.

Rijkenberg, M. J. A., Kort, R. \& Hellingwerf, K. J. (2001). Alkalispirillum mobile gen. nov., spec. nov., an alkaliphilic nonphototrophic member of the Ectothiorhodospiraceae. Arch Microbiol 175, 369-375.

Salmassi, T. M., Venkateswaren, K., Satomi, M., Nealson, K. H., Newman, D. K. \& Hering, J. G. (2002). Oxidation of arsenite by Agrobacterium albertimagni, AOL15, sp. nov., isolated from Hot Creek, California. Geomicrobiol J 19, 53-66.

Santini, J. M. \& vanden Hoven, R. N. (2004). Molybdenumcontaining arsenite oxidase of the chemolithoautotrophic arsenite oxidizer strain NT-26. J Bacteriol 186, 1614-1619.

Santini, J. M., Sly, L. I., Schnagl, R. D. \& Macy, J. M. (2000). A new chemolithoautotrophic arsenite-oxidizing bacterium isolated from a gold mine: phylogenetic, physiological, and preliminary biochemical studies. Appl Environ Microbiol 66, 92-97.

Senn, D. B. \& Hemond, H. F. (2002). Nitrate controls on iron and arsenic in an urban lake. Science 296, 2373-2376.

Silver, S. \& Phung, L. T. (2005). Genes and enzymes involved in bacterial oxidation and reduction of inorganic arsenic. Appl Environ Microbiol 71, 599-608. 
Sorokin, D. Y., Zhilina, T. N., Lysenko, A. M., Tourova, T. P. \& Spiridonova, E. M. (2006). Metabolic versatility of haloalkaliphilic bacteria from soda lakes belonging to the AlkalispirillumAlkalilimnicola group. Extremophiles 10, 213-220.

Stolz, J. F., Basu, P., Santini, J. M. \& Oremland, R. S. (2006). Arsenic and selenium in microbial metabolism. Annu Rev Microbiol 60, 107-130.

Switzer Blum, J., Burns Bindi, A., Buzzelli, J., Stolz, J. F. \& Oremland, R. S. (1998). Bacillus arsenicoselenatis sp. nov., and Bacillus selenitireducens sp. nov.: two haloalkaliphiles from Mono Lake, California which respire oxyanions of selenium and arsenic. Arch Microbiol 171, 19-30.

Swofford, D. L. (2002). PAUP*: Phylogenetic analysis using parsimony (* and other methods), version 4. Sunderland, MA: Sinauer Associates.

Tabita, F. R. \& McFadden, B. A. (1976). Molecular and catalytic properties of ribulose 1,5-bisphosphate carboxylase from the photosynthetic extreme halophile Ectothiorhodospira halophila. J Bacteriol 126, 1271-1277. vanden Hoven, R. N. \& Santini, J. M. (2004). Arsenite oxidation by the heterotroph Hydrogenophaga sp. str. NT-14: the arsenite oxidase and its physiological electron acceptor. Biochim Biophys Acta 1656, 148-155.

Wayne, L. G., Brenner, D. J., Colwell, R. R., Grimont, P. A. D., Kandler, O., Krichevsky, M. I., Moore, L. H., Moore, W. E. C., Murray, R. G. E. \& other authors (1987). International Committee on Systematic Bacteriology. Report of the ad hoc committee on reconciliation of approaches to bacterial systematics. Int J Syst Bacteriol 37, 463-464.

Yakimov, M. M., Giuliano, L., Chernikova, T. N., Gentile, G., Abraham, W.-R., Lünsdorf, H., Timmis, K. N. \& Golyshin, P. N. (2001). Alcalilimnicola halodurans gen. nov., sp. nov., an alkaliphilic, moderately halophilic and extremely halotolerant bacterium, isolated from sediments of soda-depositing Lake Natron, East Africa Rift Valley. Int J Syst Evol Microbiol 51, 2133-2143.

Zumft, W. (1997). Cell biology and molecular basis of denitrification. Microbiol Mol Biol Rev 61, 533-616. 